\title{
Article \\ Comparison of the Impact of Different Types of nZVI on Lolium westerwoldicum
}

\author{
Lidia Mielcarz-Skalska $^{1, *}$, Beata Smolińska ${ }^{1}$ (D) and Małgorzata Szynkowska-Jóźwik ${ }^{2}$ \\ 1 Institute of Natural Products and Cosmetics, Faculty of Biotechnology and Food Science, \\ Lodz University of Technology, Stefanowskiego 4/10, 90-924 Lodz, Poland; beata.smolinska@p.lodz.pl \\ 2 Surface and Track Analysis Laboratory, Institute of General and Ecological Chemistry, Faculty of Chemistry, \\ Lodz University of Technology, 90-924 Lodz, Poland; malgorzata.szynkowska-jozwik@p.lodz.pl \\ * Correspondence: lidia.mielcarz-skalska@dokt.p.lodz.pl
}

Citation: Mielcarz-Skalska, L.;

Smolińska, B.; Szynkowska-Jóźwik, M. Comparison of the Impact of Different Types of nZVI on Lolium westerwoldicum. Agronomy 2021, 11, 467. https://doi.org/10.3390/ agronomy 11030467

Academic Editor:

Pablo Martín-Ramos

Received: 27 January 2021

Accepted: 26 February 2021

Published: 3 March 2021

Publisher's Note: MDPI stays neutral with regard to jurisdictional claims in published maps and institutional affiliations.

Copyright: (c) 2021 by the authors. Licensee MDPI, Basel, Switzerland. This article is an open access article distributed under the terms and conditions of the Creative Commons Attribution (CC BY) license (https:// creativecommons.org/licenses/by/ $4.0 /)$.

\begin{abstract}
Increasing environmental pollution causes the search for new methods of purification. Currently, the remediation potential of nanoparticles is increasingly being studied. Unfortunately, there is still a lack of data on the impact of these compounds on living organisms, including plants. This study was designed to test the effects of nanoFER 25 and nanoFER 25 S iron on Lolium westerwoldicum Breakw. After cultivation of plants in a soil contaminated with nanoparticles, the biometric parameters, content of polyphenols, flavonoids, chlorophyll changes, carotenoids, anthocyanins, superoxide dismutase, catalase and pyrogallol peroxidase were studied. The conducted experiment showed that nano zero-valent iron (nZVI) is slightly taken from the soil to the plants. The iron passes to the root but there is no further transport up the plant. The content of polyphenols and flavonoids in aboveground parts of plants decreases with a simultaneous increase in roots compared to the control sample. The chlorophyll content in the leaves is strongly related to the concentration of the contaminant. Similarly, the enzyme activity of the antioxidant system in the whole plant is strongly related to the concentration of the pollutant. The amount of vegetable pigments in the leaves increases for low concentrations of contamination and then decreases at higher levels of contamination. The study has shown that both types of nanoFER are not indifferent to the plants' growth.
\end{abstract}

Keywords: Lolium westerwoldicum; nZVI; nano zero valent iron; phytotoxicity

\section{Introduction}

Currently, one of the biggest problems of modern science is environmental pollution. The increasing number of landfills, production plants, oil fields, mines and industrial plants causes more pollution enter the ecosystem. One of the biggest threats is the insertion of harmful compounds into the soil and further into aquifers [1,2].

A relatively new solution is the use of nanoremediation. This method involves the use of very small particles, at the nanoscale, that allow detection, prevention and monitoring of pollution. However, the direct application of nanoremediation, understood as insertion of nanomaterials into the contaminated environment, is not always fully studied $[1,3]$.

The last few years have brought a lot of reports about the high efficiency of nano zero-valent iron (nZVI) used for the purification of soil and water environments from heavy metals and other pollutants. Many potential applications in which nZVI can be used for remediation will probably be based on the continuous use of microorganisms and plants [4].

The small size of nZVI is a guarantee of its high reactivity and mobility, greater than molecular forms. In addition, concentrated nZVI suspensions are directly injected into the soil near the pollution, and there is no need for additional measures (e.g., excavations). As a result, nZVI is considered as a promising remediation strategy for a wide range of applications and environments [5]. 
nZVI consists of a zero-valent iron, around which there is an oxide-iron coating. In addition, nZVI can be coated with polymers, surfactants or polyelectrolytes. It has been proven that uncoated nanoparticles aggregate quickly, which results in the reduction of their active surface area and hence also in reactivity. Molecular coatings are designed to stop this process and increase the stability of nZVI suspensions [6].

$\mathrm{Fe}^{0}$ 's surface quickly undergoes an oxidation reaction to hydroxides or oxyhydroxides. This metal form $\left(\mathrm{Fe}^{0}\right)$ is stable only under reducing conditions. The formation of the iron oxide shell reduces the reactivity of nZVI. The removal of impurities by nZVI under aerobic conditions may be stopped due to a limited amount of remaining $\mathrm{Fe}^{0}$. An additional problem is the water environment, where iron can corrode. Under anaerobic conditions, $\mathrm{Fe}^{0}$ is oxidized by two reactions: with pollution and with water. In most of the contaminated sources nZVI will probably be transformed from $\mathrm{Fe}^{0}$ to $\mathrm{Fe}^{2+}$, and further to $\mathrm{Fe}^{3+}$. $\mathrm{The} \mathrm{Fe}^{2+}$ form is the most toxic to microorganisms and invertebrates, but quickly transforms into $\mathrm{Fe}^{3+}$ in a neutral and alkaline $\mathrm{pH}[1,6,7]$.

All these factors make a necessity to carry out thorough research both on the behavior of nZVI in the environment and its effect on living organisms. The use of nZVI for phytoremediation purposes should be preceded by investigation of its phytotoxicity.

Due to the increasing use of nanoparticles, it is necessary to study their impact on living organisms, including plants. The new types of soil fertilizers have been extensively searched to improve agricultural production. Iron, as an essential element for plants, exists in soil mainly in the form of its cation $\mathrm{Fe}^{3+}$, and in that form is mostly unavailable for plants. Moreover, Fe concentration in soil is usually high, but a large proportion is fixed to soil particles which results in its lowered bioavailability [8]. The main hypothesis of the work is the analysis of possibility of nZVI use in soil fertilization. However, that kind of investigation has to be preceded by detailed studies of nZVI effects on the plant growth. Therefore, the aim of the experiment was to investigate the phytotoxicity of nZVI in the form of nanoFER 25 and nanoFER 25S to Lolium westerwoldicum Breakw. The influence of nZVI in both forms on plant biometric parameters, chlorophyll content and chosen elements of plant antioxidant systems was examined.

\section{Materials and Methods}

\subsection{Pot Experiment}

L. westerwoldicum was cultivated in the soil, whose characteristics are presented in Table 1. nZVI, in the forms of 25 nanoFER and 25S nanoFER which were used in the study, was purchased from Nano Iron (Rajhrad, Czech Republic). NanoFER 25 consists of iron (Fe) at $14-18 \%$ of weight content; $2-6 \%$ weight content of iron oxide $\left(\mathrm{Fe}_{3} \mathrm{O}_{4}\right), 0-1 \%$ weight content of carbon (C) and water at $80 \%$ of weight content. The composition of nanoFER $25 \mathrm{~S}$ is as follows (in \% of weight content): $14-18 \%$ of $\mathrm{Fe}, 2-6 \%$ of $\mathrm{Fe}_{3} \mathrm{O}_{4}, 0-1 \%$ of $\mathrm{C}, 77 \%$ of water and 3\% of surfactants [9]. NanoFER 25, used in the study, is a reactive aqueous dispersion of Fe (0) nanoparticles without any organic or inorganic modifications. It is characterized by high reactivity, a high degree of agglomeration and fast sedimentation. NanoFER 25S is a water dispersion of Fe (0) nanoparticles with biodegradable organic surface modification. Both forms are black with a size $<50 \mathrm{~nm}$, specific surface $>25 \mathrm{~m}^{2} / \mathrm{g}$ and a pH of 11-12 [9]. The 25 nanoFER and 25S nanoFER were introduced into the soil as a liquid, separately, in concentrations of $0.5 ; 1 ; 5 ; 10 ; 50$ and $100 \mathrm{~g} \mathrm{~kg}^{-1}$ of dry weight of soil, respectively. Soil supplemented by $n Z V I$ was homogenized and left for stabilization for $4 \mathrm{~h}$. Soil without nZVI was determined as the control. The whole investigation was conducted on thirteen variants, each in triplicate. 
Table 1. Soil characteristics.

\begin{tabular}{cc}
\hline Parameter & Content \\
\hline $\mathrm{C}_{\text {org }}$ & $35.74 \%$ \\
\hline $\mathrm{N}$ total & $0.071 \mathrm{mg} / \mathrm{g}$ \\
\hline $\mathrm{SO}_{4}{ }^{2-}$ & $168 \mathrm{mg} / \mathrm{L}$ \\
\hline $\mathrm{Mg}$ & $54 \mathrm{mg} / \mathrm{L}$ \\
\hline $\mathrm{K}$ & $3.8 \mathrm{mg} / \mathrm{g}$ \\
\hline $\mathrm{Ca}$ & $292.5 \mathrm{mg} / \mathrm{L}$ \\
\hline $\mathrm{Mn}$ & $37.5 \mu \mathrm{g} / \mathrm{g}$ \\
\hline $\mathrm{P}$ total & $24.4 \mathrm{mg} / \mathrm{L}$ \\
\hline $\mathrm{Cl}^{-}$ & $<1.9 \mathrm{~g} / \mathrm{L}$ \\
\hline $\mathrm{pH}$ & 6.0 \\
\hline
\end{tabular}

L. westerwoldicum seeds (KUDO, Pszczyna, Polska) were introduced on the surface of control and contaminated soil samples in the amount of $0.5 \mathrm{~g}$ per $\mathrm{kg}$ of dry weight of soil. L. westerwoldicum plants were cultivated for 6 weeks in a green house in a day/night system of $14 / 10 \mathrm{~h}$, average day/night temperature of $22 / 19{ }^{\circ} \mathrm{C}$ and air humidity of $50 \%$. During the growth period plants were watered with deionized water in the amount suitable for keeping soil humidity at the level of $35 \%$. After the cultivation process, plants were harvested, watered with deionized water to remove soil particles, weighed and subjected to further analysis.

\subsection{Determination of Iron Content in Plants}

Determination of Fe concentration in the plants was made by atomic absorption spectrometry (AAS) (Absorption Atomic Spectrophotometer, GBC 932, (GBC Scientific Equipment Ltd., Dandenong, VIC, Australia)), by the flame method with acetylene oxygen gas, at detection level 2-9 $\mu \mathrm{g} / \mathrm{mL}$, after microwave mineralization. Microwave mineralization was conducted in a Magnum II by ERTEC (ERTEC-Poland Dr Edward Reszke, Wrocław, Poland). The sample was flooded with $6 \mathrm{~mL}$ of $65 \%$ nitric acid (V) and placed in the apparatus for $5 \mathrm{~min}$ at $85 \%$ power, then $30 \mathrm{~s}$ for a break, and another $10 \mathrm{~min}$ at $60 \%$ power. Finally, it was cooled for $10 \mathrm{~min}$ and poured into a flask through a filter.

\subsection{Biometric Parameters}

Biometric parameters of $L$. westerwoldicum were determined on five representative plants chosen randomly from the pots of each variant of experiment in accordance with the procedure described by Wulfsohn (2010) [10]. The length of whole plant and the length of below and above ground parts of L. westerwoldicum were measured.

\subsection{Plant Pigments Analysis}

Determination of chlorophyll $a, b$, total carotenoids and anthocyanins was provided according to Israelstam and Hiscox (1979) [11]. $0.1 \mathrm{~g}$ of aboveground plant tissue was mixed with $2.5 \mathrm{~mL}$ dimethyl sulfoxide (DMSO). The samples were incubated in room temperature for $1 \mathrm{~h}$ in the darkness and after that were subjected to a water bath at $65^{\circ} \mathrm{C}$ for $30 \mathrm{~min}$. Amounts of chlorophyll $a, b$ and carotenoids were determined on a UV/VIS8453 spectrophotometer Spectroquant Nova 400 (Merck KGaA, Darmstadt, Germany) at the following wavelengths: $663 \mathrm{~nm}$ (chlorophyll $a$ ), $645 \mathrm{~nm}$ (chlorophyll $b$ ), $470 \mathrm{~nm}$ (carotenoids) and $534 \mathrm{~nm}$ (anthocyanins). The content of plant pigments was calculated according to the Arnon formula (1949) [12] with modification by Richardson et al. (2002). The amount of individual pigments was given in $\mathrm{mg} / \mathrm{g}$ of fresh weight of the plant [13]. 


\subsection{Determination of Polyphenols}

Analysis of total polyphenol content in aboveground plant tissues was carried out according to the procedure described by Meng et al. (2009) [14]. $0.5 \mathrm{~g}$ of plant tissue were homogenized with a $5 \mathrm{~mL}$ of $80 \%$ methanol. The samples were then centrifuged for $20 \mathrm{~min}$ at $15,000 \mathrm{rpm}$. The test sample contained $50 \mu \mathrm{L}$ of extract, $3.85 \mathrm{~mL}$ of distilled water, $100 \mu \mathrm{L}$ of Folin reagent (incubation for $3 \mathrm{~min}$ at room temperature) and $1 \mathrm{~mL}$ of $10 \% \mathrm{Na}_{2} \mathrm{CO}_{3}$. The samples were mixed and incubated in the dark for $60 \mathrm{~min}$ at room temperature. After this time, the absorbance at $725 \mathrm{~nm}$ was measured. Polyphenol content was calculated on the basis of a standard curve. A methanol solution of gallic acid was used as a reference. The total content of polyphenols was determined as the amount of gallic acid equivalents per

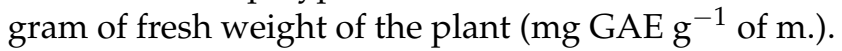

\subsection{Determination of Flavonoids Content}

Determination of flavonoids in L. westerwoldicum was based on the procedure described by Lamaison and Carnat (1990) [15]. $1 \mathrm{~g}$ of plant by fresh weight was homogenized with $5 \mathrm{~mL}$ of $80 \%$ methanol and shaken for $1 \mathrm{~h}$ at room temperature. The total flavonoid content was determined using a colorimetric method with aluminum chloride $\left(\mathrm{AlCl}_{3}\right)$. After $30 \mathrm{~min}$ of incubation at room temperature, the absorbance of the sample was tested and, without the presence of extract, was measured at a wavelength of $425 \mathrm{~nm}$. The content of flavonoids was expressed on the basis of the calibration curve as $\mathrm{mg}$ of quercetin per $1 \mathrm{~g}$ of fresh weight of the plant (mg QE/g fresh weight) [16].

\subsection{Antioxidant Enzymes Assey}

The studies were carried out to determine the superoxide dismutase (SOD) activity, pyrogallol peroxidase (POD) activity and catalase (CAT) activity.

The SOD activity was tested in accordance to Roth et al (1984) [17]. $50 \mu \mathrm{L}$ of plant extract was mixed with $1 \mathrm{~mL}$ of TRIS-EDTA buffer at $\mathrm{pH} 8.2$ and $1 \mathrm{~mL}$ of $0.2 \mathrm{mM}$ pyrogallol solution. The control sample contained $50 \mu \mathrm{L}$ of distilled water instead of the plant extract. Absorbance was measured $10 \mathrm{~min}$ after addition of pyrogallol at $420 \mathrm{~nm}$ [16]. The SOD activity was calculated according to the formula:

$$
\begin{aligned}
& \% \text { inhibition of pyrogallol autoxidation }=(\Delta A \text { test } \div \Delta A \text { control }) \times 100 \% \\
& \text { SOD activity }[U \div g f . m .]=\% \text { inhibition of pyrogallol autoxidation } \div 50 \%
\end{aligned}
$$

Determination of POD activity was prepared according to the method of Chance and Maehly (1955) [18]. $1 \mathrm{~g}$ of the sample was homogenized with an acetate buffer at $\mathrm{pH}$ 5.6, shaken for $30 \mathrm{~min}$ and then centrifuged. $100 \mu \mathrm{L}$ of the supernatant was collected and mixed with $0.9 \mathrm{~mL}$ of acetate buffer at $\mathrm{pH} 5.6,0.5 \mathrm{~mL}$ of pyrogallol and $0.5 \mathrm{~mL}$ of $\mathrm{H}_{2} \mathrm{O}_{2}$. The samples were incubated for $4 \mathrm{~min}$ at 30 degrees Celsius and then the absorbance was measured at $470 \mathrm{~nm}$. The measure of enzyme activity is the difference between absorbance with $\mathrm{H}_{2} \mathrm{O}_{2}$ and without $\mathrm{H}_{2} \mathrm{O}_{2}$ expressed in mol/g f.m. Analysis of CAT activity was carried out according to Jiang and Zhang (2002) [19]. $20 \mathrm{mg}$ of plant tissue was mixed with $800 \mu \mathrm{L}$ of phosphate buffer ( $\mathrm{pH} 7.0$ ) and then the mixture was shaken for $30 \mathrm{~min}$. The samples were then centrifuged and the filtrate was collected. $3 \mathrm{~mL}$ of extraction buffer containing $20 \mathrm{mM}$ of $\mathrm{H}_{2} \mathrm{O}_{2}, 2 \mathrm{mM}$ of phosphate buffer ( $\mathrm{pH} 7.0$ ) and $1 \mathrm{~mL}$ of enzyme extract were poured into the tube. The time needed to change the value by 0.05 units at $240 \mathrm{~nm}$ was measured on the spectrophotometer. The enzyme unit is the amount of enzyme that is able to raise the absorbance by 0.05 units within $1 \mathrm{~min}$ (U/g f.m). 


\subsection{SEM}

The study was performed on a scanning electron microscope with X-ray microanalysis (SEM-EDS) (HITACHI S-4700, EDS Thermo NORAN). The sample was dried in the air to obtain a constant mass. Before SEM imaging, the samples were sprayed with a thin layer of activated carbon and placed under a microscope. Imaging was carried out at a magnification of 5000 times. Imaging was carried out for all variants of the experiment in duplicate.

\subsection{Statistical Analysis}

The results presented in tables and figures are the mean values of five replicates with standard deviation. Significant differences between the treatments were performed using the Anova test in R-Studio. The LSD test (Fisher test) was used. Differences were considered as statistically significant when the $p$-value was $<0.05$.

\section{Results and Discussion}

\subsection{Analysis of Biometric Parameters}

In all tested concentrations of $25 \mathrm{nZVI}$ samples, a decrease in the mass of plants (Table 2) was observed (by as much as $67 \%$ for $100 \mathrm{~g}$ ) compared to the control. At the same time, for concentrations of $0.5,1$ and $5 \mathrm{~g}$ of nZVI the root and leaf mass increased slightly (12-26\%, compared to the control). In the case of $25 \mathrm{~S}$ nZVI, concentrations of 0.5 , 50 and $100 \mathrm{~g}$ caused a significant increase in both whole-plant biomass and their roots and leaves. Both 25 and $25 \mathrm{~S}$ nZVI had a stimulating effect on the growth of the entire plant (Table 3), especially on the leaf. The best effect (compared to the control) was observed for leaves at concentrations of $0.5 \mathrm{~g}$ of $25 \mathrm{nZVI}(140 \%)$ and $10 \mathrm{~g}$ of $25 \mathrm{nZVI}(127 \%)$. The results obtained for the shoots and roots were: $0.5 \mathrm{~g}-128 \%, 100 \mathrm{~g}-155 \%$ and $0.5 \mathrm{~g}-84 \%, 100 \mathrm{~g}-88 \%$ respectively. Similar research was carried out by Wang et al. (2016) on rice (Oryza sativa L.). After two weeks of exposure to concentrations of 500, 750 and $1000 \mathrm{mg}$ of $\mathrm{nZVI} / \mathrm{kg}$, they observed chlorosis and much smaller growth of seedlings. In addition, the study showed a decrease in root and shoot length by 46.9 and $57.5 \%$ for a concentration of $1000 \mathrm{mg} / \mathrm{kg}$. In the case of fresh mass, researchers observed a decrease of $46.8 \%$ (root) and $22.8 \%$ (shoots) at the same concentration of nZVI [20].

Table 2. Plant biomass after cultivation in soil supplemented by $25 \mathrm{nZVI}$ and $25 \mathrm{~S}$ nZVI.

\begin{tabular}{ccccc}
\hline & $\begin{array}{c}\text { Variant } \\
\text { (g/kg of Soil) }\end{array}$ & $\begin{array}{c}\text { Mass of } \\
\text { Biomass (g) }\end{array}$ & $\begin{array}{c}\text { Shoot } \\
\text { Mass (g) }\end{array}$ & $\begin{array}{c}\text { Root } \\
\text { Mass (g) }\end{array}$ \\
\hline & Control & $20.93 \pm 5.84(\mathrm{~b})$ & $16.53 \pm 3.53(\mathrm{a})$ & $11.74 \pm 4.13(\mathrm{~d})$ \\
\hline & $0.5 \mathrm{~g}$ & $41.23 \pm 13.66(\mathrm{a})$ & $30.10 \pm 8.84(\mathrm{a})$ & $24.77 \pm 6.53(\mathrm{a})$ \\
& $1 \mathrm{~g}$ & $36.5 \pm 7.40(\mathrm{a})$ & $28.90 \pm 6.01(\mathrm{ab})$ & $22.83 \pm 3.49(\mathrm{a})$ \\
& $5 \mathrm{~g}$ nZVI & $37.1 \pm 7.17(\mathrm{a})$ & $26.27 \pm 8.39(\mathrm{~b})$ & $17.23 \pm 1.08(\mathrm{bc})$ \\
& $10 \mathrm{~g}$ & $38.37 \pm 10.44(\mathrm{a})$ & $26.70 \pm 6.04(\mathrm{ab})$ & $18.77 \pm 1.53(\mathrm{~b})$ \\
& $50 \mathrm{~g}$ & $40.55 \pm 10.46(\mathrm{a})$ & $28.83 \pm 4.04(\mathrm{ab})$ & $14.59 \pm 3.64(\mathrm{c})$ \\
& $100 \mathrm{~g}$ & $37.05 \pm 9.66(\mathrm{a})$ & $26.72 \pm 6.20(\mathrm{~b})$ & $15.57 \pm 4.33(\mathrm{c})$ \\
\hline & Control & $20.93 \pm 5.84(\mathrm{~B})$ & $16.53 \pm 3.53(\mathrm{AB})$ & $11.74 \pm 4.13(\mathrm{~B})$ \\
\hline & $0.5 \mathrm{~g}$ & $25.27 \pm 2.73(\mathrm{AB})$ & $19.27 \pm 2.88(\mathrm{~A})$ & $13.33 \pm 6.45(\mathrm{AB})$ \\
& $1 \mathrm{~g}$ & $19.6 \pm 8.97(\mathrm{~B})$ & $15.63 \pm 3.03(\mathrm{~B})$ & $12.97 \pm 1.39(\mathrm{~B})$ \\
& $5 \mathrm{~g}$ & $17.23 \pm 3.32(\mathrm{~B})$ & $13.53 \pm 2.21(\mathrm{~B})$ & $5.70 \pm 1.32(\mathrm{C})$ \\
& $10 \mathrm{~g}$ & $19.92 \pm 8.86(\mathrm{~B})$ & $15.37 \pm 6.83(\mathrm{~B})$ & $15.22 \pm 3.96(\mathrm{AB})$ \\
& $50 \mathrm{~g}$ & $21.43 \pm 7.14(\mathrm{~B})$ & $16.67 \pm 2.59(\mathrm{AB})$ & $15.77 \pm 2.68(\mathrm{~A})$ \\
& $100 \mathrm{~g}$ & $30.02 \pm 9.44(\mathrm{~A})$ & $20.58 \pm 2.31(\mathrm{~A})$ & $13.43 \pm 2.45(\mathrm{AB})$ \\
\hline
\end{tabular}

Means $(\mathrm{n}=5) \pm$ standard deviation. Different letters indicate significant difference at $p<0.05$ by LSD test: letters a, b, c-for nanoFER 25 treatments; letters A, B, C-for nanoFER 25S treatments. 
Table 3. Plant biometric parameters-length of root, shoot and whole plant.

\begin{tabular}{ccccc}
\hline & $\begin{array}{c}\text { Variant } \\
\text { (g/kg of Soil) }\end{array}$ & $\begin{array}{c}\text { Root } \\
\text { Length }(\mathbf{c m})\end{array}$ & $\begin{array}{c}\text { Shoot } \\
\text { Length } \mathbf{( c m})\end{array}$ & $\begin{array}{c}\text { Plant } \\
\text { Length (cm) }\end{array}$ \\
\hline Control & $10.83 \pm 3.18(\mathrm{e})$ & $14.90 \pm 1.35(\mathrm{~cd})$ & $22.40 \pm 1.65(\mathrm{~d})$ \\
\hline & $0.5 \mathrm{~g}$ & $19.1 \pm 0.69(\mathrm{a})$ & $18.70 \pm 1.39(\mathrm{a})$ & $34.47 \pm 7.85(\mathrm{a})$ \\
& $1 \mathrm{~g}$ & $12.5 \pm 3.06(\mathrm{~d})$ & $17.43 \pm 0.7(\mathrm{~b})$ & $26.60 \pm 1.04(\mathrm{c})$ \\
& $5 \mathrm{~g}$ nZVI & $17.73 \pm 0.40(\mathrm{~b})$ & $15.47 \pm 1.79(\mathrm{c})$ & $29.87 \pm 7.16(\mathrm{~b})$ \\
& $10 \mathrm{~g}$ & $19.70 \pm 2.25(\mathrm{a})$ & $13.93 \pm 0.75(\mathrm{~d})$ & $30.30 \pm 7.27(\mathrm{~b})$ \\
& $50 \mathrm{~g}$ & $15.87 \pm 1.96(\mathrm{c})$ & $14.47 \pm 1.79(\mathrm{~d})$ & $27.00 \pm 5.53(\mathrm{c})$ \\
& $100 \mathrm{~g}$ & $13.57 \pm 0.12(\mathrm{~d})$ & $13.60 \pm 1.56(\mathrm{~d})$ & $23.83 \pm 2.32(\mathrm{~d})$ \\
\hline & Control & $10.83 \pm 3.18(\mathrm{~B})$ & $14.90 \pm 1.35(\mathrm{AB})$ & $22.40 \pm 1.65(\mathrm{~B})$ \\
\hline & $0.5 \mathrm{~g}$ & $13.2 \pm 0.35(\mathrm{~A})$ & $15.60 \pm 1.56(\mathrm{~A})$ & $25.47 \pm 4.99(\mathrm{~A})$ \\
& $1 \mathrm{~g}$ & $11.57 \pm 1.85(\mathrm{AB})$ & $14.63 \pm 1.50(\mathrm{~B})$ & $22.87 \pm 5.43(\mathrm{AB})$ \\
& $5 \mathrm{~g}$ & $11.60 \pm 1.04(\mathrm{AB})$ & $13.10 \pm 1.91(\mathrm{C})$ & $21.37 \pm 2.83(\mathrm{~B})$ \\
& $10 \mathrm{~g}$ & $10.47 \pm 2.54(\mathrm{~B})$ & $14.53 \pm 1.79(\mathrm{~B})$ & $21.67 \pm 1.44(\mathrm{~B})$ \\
& $50 \mathrm{~g}$ & $12.53 \pm 0.06(\mathrm{~A})$ & $14.40 \pm 0.17(\mathrm{~B})$ & $23.60 \pm 5.89(\mathrm{AB})$ \\
& $100 \mathrm{~g}$ & $12.73 \pm 1.33(\mathrm{~A})$ & $15.37 \pm 2.83(\mathrm{~A})$ & $24.77 \pm 1.93(\mathrm{~A})$ \\
\hline
\end{tabular}

Means $(\mathrm{n}=5) \pm$ standard deviation. Different letters indicate significant difference at $p<0.05$ by LSD test: letters $\mathrm{a}, \mathrm{b}, \mathrm{c}$ - for nanoFER 25 treatments; letters A, B, C-for nanoFER $25 \mathrm{~S}$ treatments.

Ma et al. (2013) observed toxicity symptoms in the case of Typha latifolia. Plants growing in the nZVI-contaminated environment at concentrations higher than $200 \mathrm{mg} / \mathrm{L}$ were significantly shorter than the control group, while nZVI $(<50 \mathrm{mg} / \mathrm{L})$ had a stimulating effect on the growth of broadleaf parts. Plants treated with $200 \mathrm{mg}$ of nZVI/L had many dry leaves and were characterized by lower biomass than control plants (for concentration of $1000 \mathrm{mg} / \mathrm{L}$ biomass was $6.93 \%$ lighter). The higher the dose of soil amendment the longer were the roots of T. latifolia [21]. El-Temsah et al. (2010) observed first negative reactions for germinating seeds in the absence of soil at $250 \mathrm{mg} / \mathrm{L}$, where the growth of flax shoots and the growth of barley roots decreased. At higher concentration levels all species (flax, barley and ryegrass) and all parameters showed a negative effect of nZVI on plants. In the case of soil, a negative effect was observed on all species and all parameters at a concentration of $300 \mathrm{mg} \mathrm{nZVI/L} \mathrm{in} \mathrm{soil} \mathrm{water} \mathrm{[4].} \mathrm{Marusenko} \mathrm{and} \mathrm{others} \mathrm{(2013)} \mathrm{showed} \mathrm{that} A$. thaliana plants grown with a presence of nanoparticle hematite (NP) showed visible signs of $\mathrm{Fe}$ deficiency. Plants cultivated with NP-Fe did not grow as large, contained less chlorophyll and had lower internal concentrations of Fe than plants grown with EDTA-Fe [22].

\subsection{Iron Content and SEM Imaging}

The iron content in the leaves of the tested plants (Figure 1i) when using nZVI was at a similar level regardless the variant. The exception was the concentration of $100 \mathrm{~g}$ of $\mathrm{nZVI} / \mathrm{kg}$ soil. The leaves contained different amounts of $25 \mathrm{~S} \mathrm{nZVI}$ and the content of nZVI in the roots increased with the increase of the concentration of soil amendment. At concentrations of $0.5-5 \mathrm{~g} \mathrm{nZVI} / \mathrm{kg}$ soils the level of amendment in the root (Figure 1ii) was at a similar level as in the control. SEM imaging showed that while a small amount of iron could be detected in the root (Figure 2), the presence of this element was not observed in the leaves (Figure 3). 


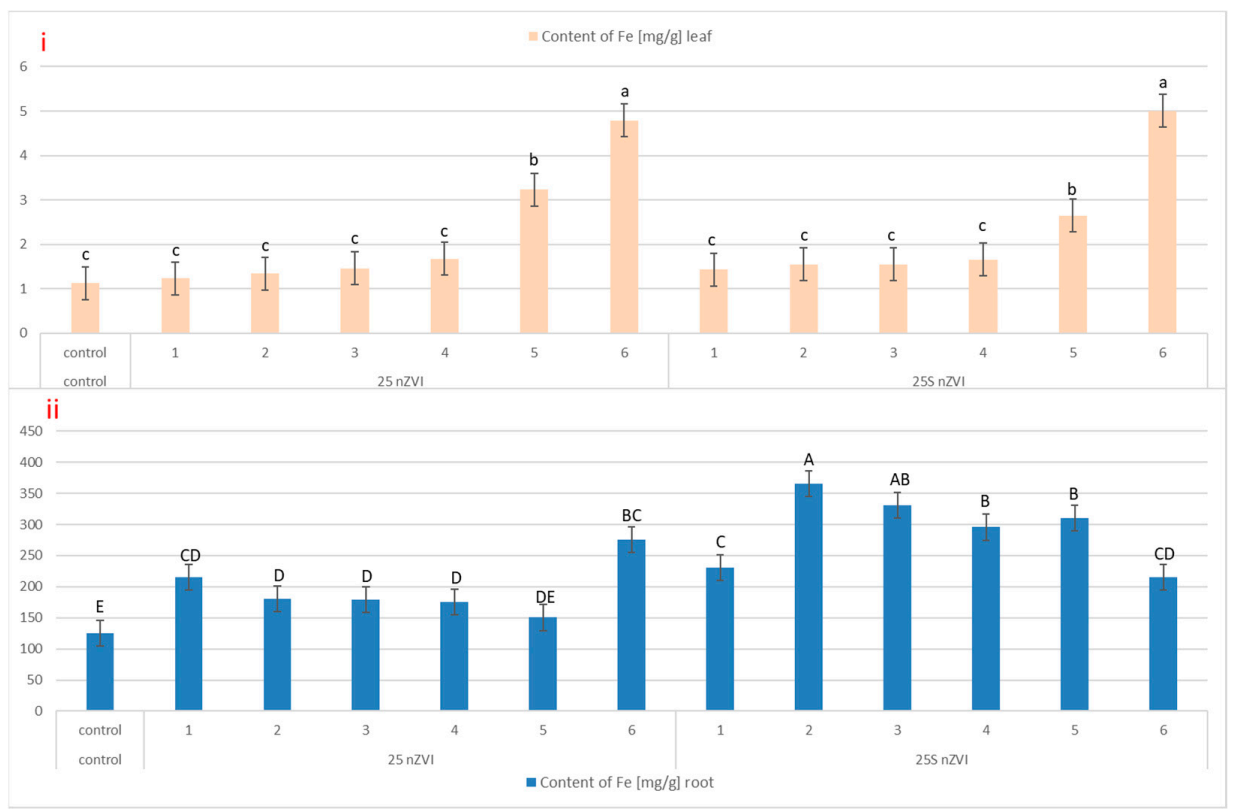

Figure 1. The concentration of iron (mg/g of soil) in the shoots (i) and roots (ii) of plants grown on soil contaminated with 25 and $25 \mathrm{~S}$ nZVI. The numbers $1-6$ correspond to the following concentrations: $0.5 ; 1 ; 5 ; 10 ; 50$ and $100 \mathrm{~g} \mathrm{nZVI} / \mathrm{kg}$ soil. Vertical bars represents the mean values $(\mathrm{n}=5) \pm$ standard deviations. Different letters indicate significant difference at $p<0.05$ by LSD test.
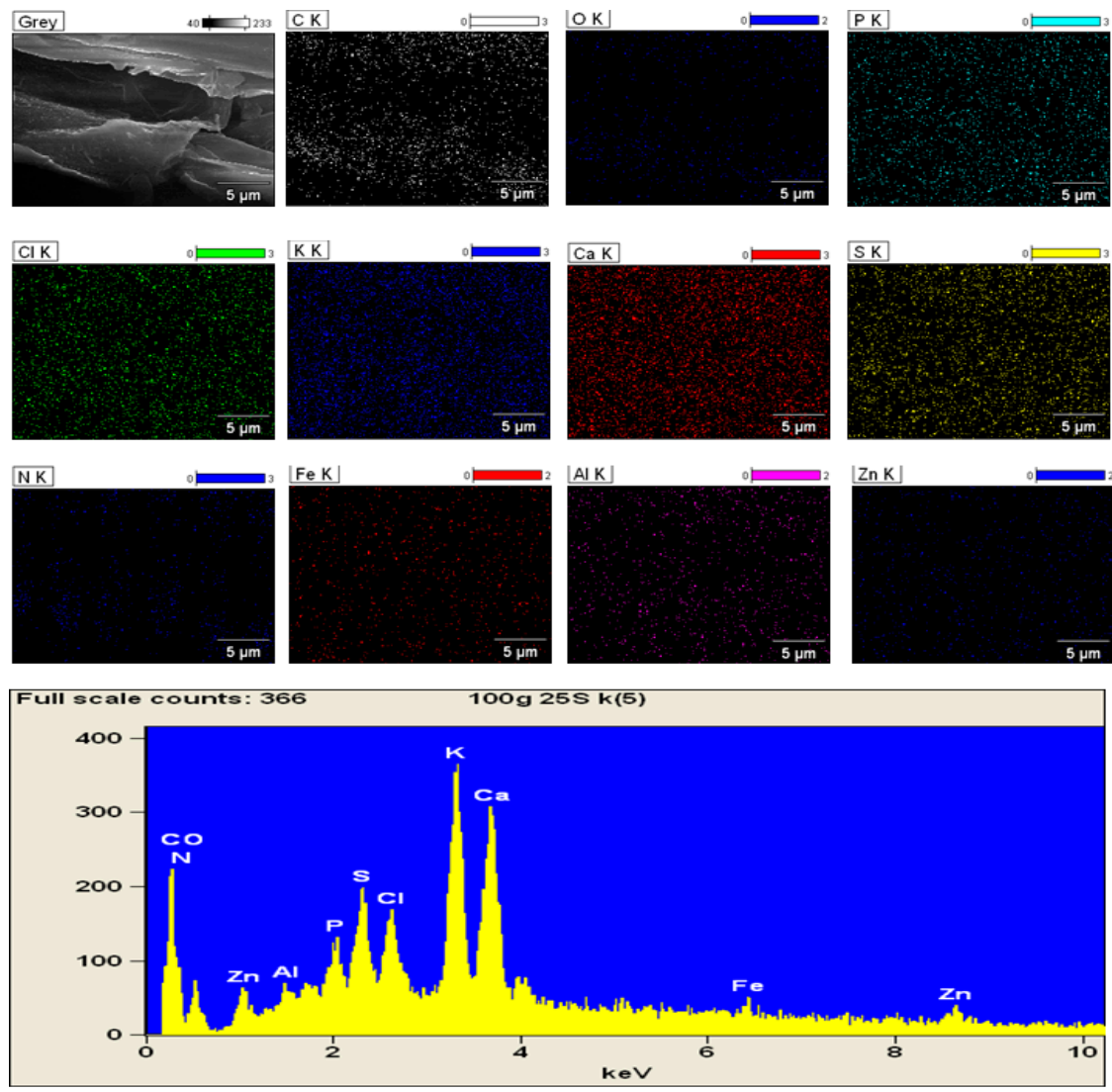

Figure 2. Scanning electron microscope (SEM) analysis of roots for $100 \mathrm{~g} 25 \mathrm{~S} \mathrm{nZVI} / \mathrm{kg}$ of soil. 


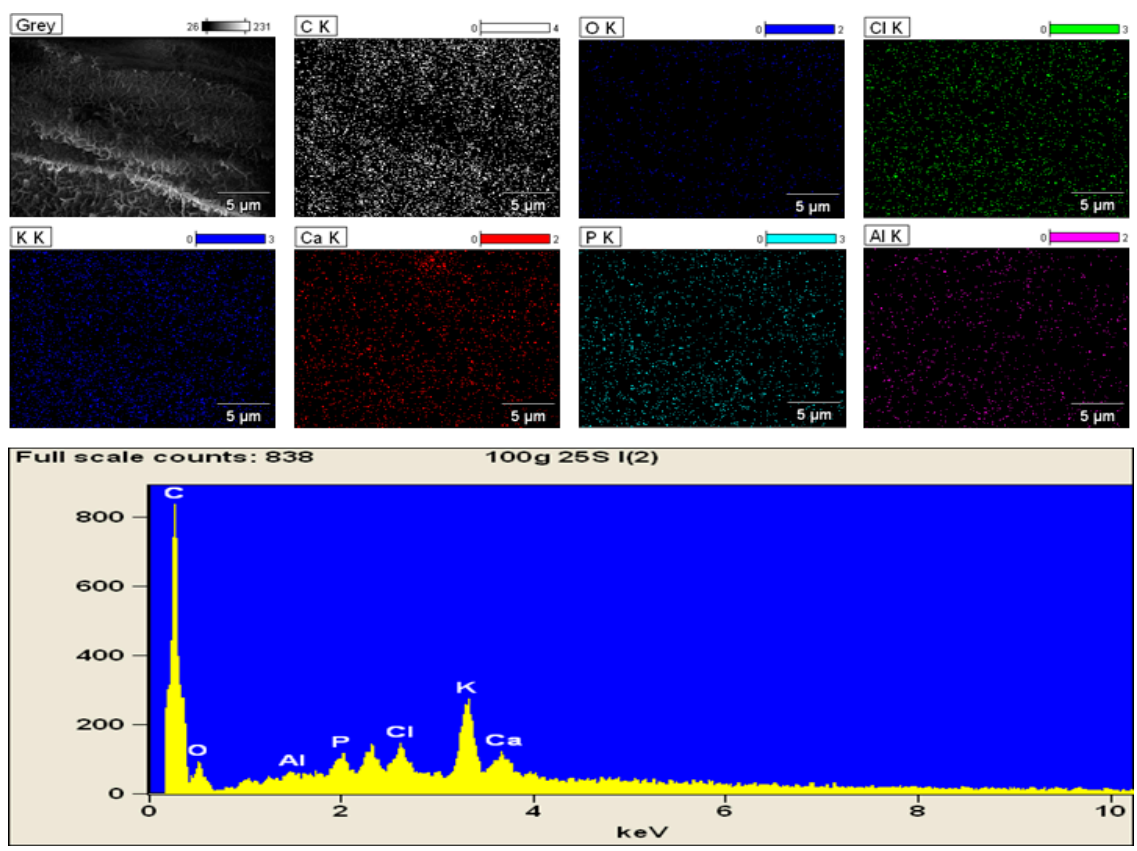

Figure 3. SEM analysis of shoots for $100 \mathrm{~g} 25 \mathrm{~S}$ nZVI/ $\mathrm{kg}$ of soil.

According to Fajardo et al. (2015) nZVI has no negative impact on soil and has the ability to increase the bioavailability of iron [2]. Martínez-Fernández et al. (2016) showed that nZVI adhered to the roots and was not transferred to the shoots, nor even uptaken from the soil. Under the microscope, it was observed that nZVI was present in the outer layers of roots. Researchers suspect that nZVI is unable to penetrate the cell membrane [23]. A study by Gil-Díaz et al. (2015) showed reduction of iron content in leaves [24]. Yirsaw et al. (2016) showed that mixed forms of iron oxides improve remediation processes. Thanks to Fenton's reaction, iron can remove heavy metals, e.g., by co-precipitation or absorption [25]. Wang et al. (2016) observed that at a concentration of $1000 \mathrm{mg} / \mathrm{kg}$ of nZVI soil, total and available iron in the soil was no less than in the case of control. The total iron content in the root was higher than in the shoot. In addition, high doses $(500,750$ and $1000 \mathrm{mg} / \mathrm{kg}$ of soil) increased its content in the root. SEM imaging showed destruction of the cell wall of the root cells but no nZVI were observed in the vessels of the plant. ESD imaging showed that nanoparticles can pass through the epidermis via apoplastic pathways, but not through the transportable pathway [20]. According to Ma et al. (2012), nZVI penetrates epidermal cells and internalizes poplar cells [21].

\subsection{Non-Enzymatic Cell Metabolites - Content of Polyphenols and Flavonoids}

The content of polyphenols in the aboveground part (Figure 4i) abruptly drops by about $70 \%$ in all variants compared to the control for both types of iron nanoparticles. Both 25 and 25S nZVI cause a significant decrease in the flavonoids content (Figure 4i) in the leaves (by about 30\%). The only exception is the concentration of $0.5 \mathrm{~g}$ of $25 \mathrm{nZVI}$, where an increase of $90 \%$, compared to the control, was observed. When using both nanoparticles, the content of polyphenols in the roots, compared to the control, (Figure 4ii) increased sharply by more than $200 \%$. The largest, 13-fold, increase was observed for $0.5 \mathrm{~g}$ of $25 \mathrm{nZVI}$ and 8-fold for $1 \mathrm{~g}$ of $25 \mathrm{~S}$ nZVI. The amount of flavonoids in the roots (Figure 4iii), like polyphenols, increased regardless the type of soil amendment. The exceptions were two concentrations of $25 \mathrm{nZVI}: 10 \mathrm{~g}$ (decrease by 8\%) and $100 \mathrm{~g}$ (decrease by 7\%) compared to the control. 


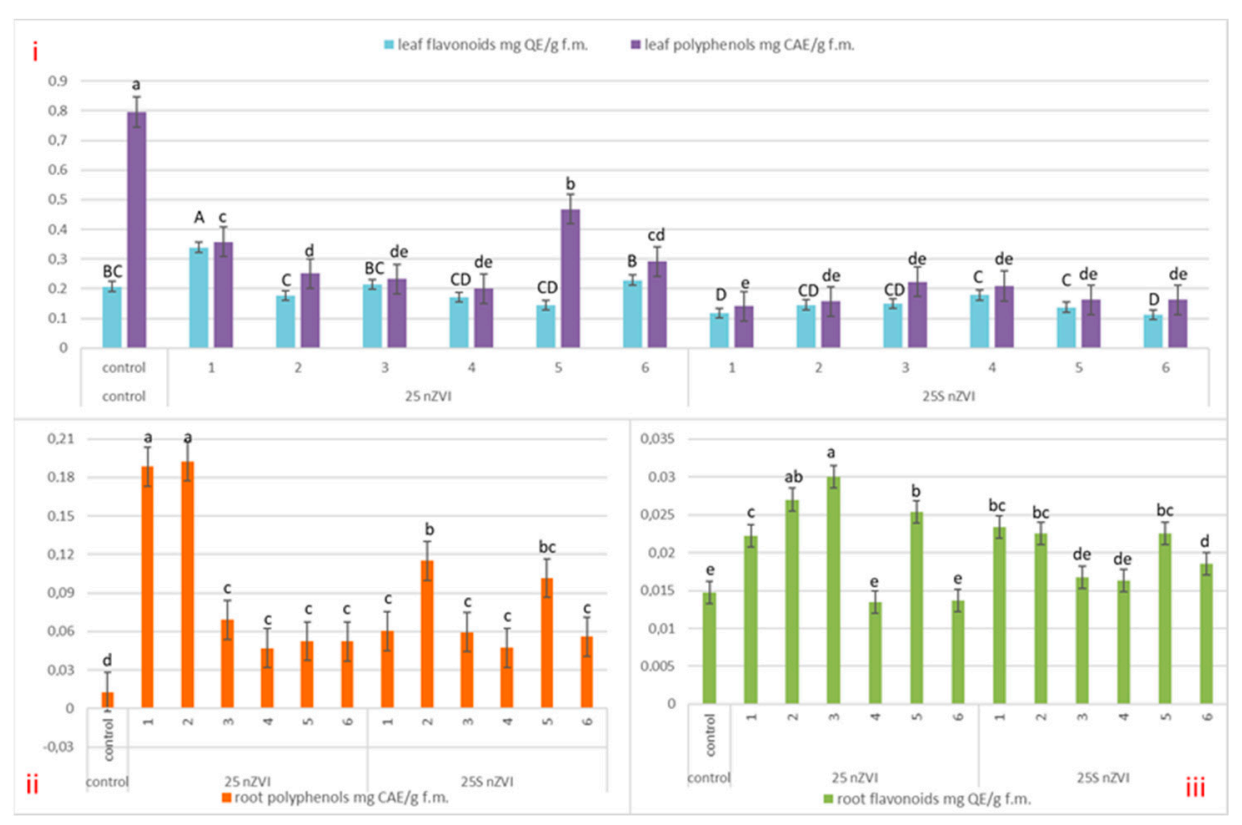

Figure 4. The content of polyphenols and flavonoids in the shoots (i) and content of flavonoids (ii) and polyphenols (iii) in roots of plants grown on soil contaminated with 25 and $25 \mathrm{~S}$ nZVI. The numbers 1-6 correspond to the following concentrations: $0.5 ; 1 ; 5 ; 10 ; 50$ and $100 \mathrm{~g} \mathrm{nZVI} / \mathrm{kg}$ soil. Vertical bars represents the mean values $(n=5) \pm$ standard deviations. Different letters indicate significant difference at $p<0.05$ by LSD test.

Fazlzadeh et al. (2017) showed that polyphenols have a reducing effect on iron and may prevent its aggregation [26]. This is interesting as the use of nanoparticles and polyphenol complexes can improve environmental remediation processes. This effect was observed by several research groups, including Wang et al. (2014) [27]. However, there are no studies on the non-enzymatic response of plants to nanoparticle iron.

\subsection{Plants Pigments-Chlorophyll a and b, Carotenoids and Anthocyanin}

The content of chlorophyll $a$ (Figure 5) was reduced by about $20 \%$ for 5 and $10 \mathrm{~g}$ of $\mathrm{nZVI}$ and $10 \%$ for $100 \mathrm{~g}$ of nZVI, compared to the control. However, for concentrations of 0.5 and $50 \mathrm{~g}$ of $25 \mathrm{nZVI}$ an increase in the content of chlorophyll $a$ by $10 \%$ was observed. In case of $25 \mathrm{~S}$ nZVI a slight increase was noticed only at a concentration of $5 \mathrm{~g}$, while the remaining variants of the experiment caused a decrease to $20 \%$ for the three highest concentrations. The content of chlorophyll $b$ (Figure 5) for $0.5 \mathrm{~g}$ of nZVI $/ \mathrm{kg}$ of soil increased by $63 \%$ and $50 \mathrm{~g}$ of nZVI by $40 \%$, compared to the control. Other variants of this type of nanoparticle, as well as all concentrations of $25 \mathrm{~S} \mathrm{nZVI}$, caused a decrease compared to the control in the content of chlorophyll $b$.

The content of leaf anthocyanins (Figure 6i) increases by $95 \%$ for $5 \mathrm{~g}$ of nZVI, $58 \%$ for $0.5 \mathrm{~g}$ of $25 \mathrm{nZVI}$ and $22 \%$ for $10 \mathrm{~g}$ of $25 \mathrm{~S} \mathrm{nZVI}$ compared to the control group. In contrast, compared to the control decreases were observed for concentrations of $50 \mathrm{~g}$ of nZVI by $20 \%$ (25)-30\% (25S) and for $100 \mathrm{~g}$ of nZVI 35\% (25)-57\% (25S). The content of carotenoids in the leaves (Figure 6iii), compared to the control, increased by $34 \%$ for $0.5 \mathrm{~g}$ of $25 \mathrm{nZVI}$ and $14 \%$ for $50 \mathrm{~g}$ of nZVI. The remaining variants of the experiment showed a decrease in the amount of carotenoids for $25 \mathrm{nZVI}$, as well as the highest concentrations used for $25 \mathrm{~S}$ nZVI: $26 \%$ for $50 \mathrm{~g}$ and $33 \%$ for $100 \mathrm{~g}$. The content of anthocyanin in the roots (Figure 6iii) was dependent on the concentration of the contaminant. The highest increase (compared to the control) for $25 \mathrm{nZVI}$ was observed for $100 \mathrm{~g}(260 \%)$ and $0.5 \mathrm{~g}(128 \%)$. The decrease was noticed in only one case, for $50 \mathrm{~g}$ of $25 \mathrm{nZVI}$, by $43 \%$. NanoFER $25 \mathrm{~S}$ caused an increase in the amount of anthocyanin by up to $248 \%$ ( $5 \mathrm{~g}$ ) and $317 \%$ (50 g). A similar relationship was also observed for the content of carotenoids in the roots (Figure 6ii). $25 \mathrm{~S}$ nanoparticles 
caused an increase in all variants of the experiment (up to $280 \%$ for $50 \mathrm{~g}$ of $25 \mathrm{~S} \mathrm{nZVI}$ ) compared to the control. $25 \mathrm{nZVI}$ caused a smaller increase in carotenoid concentration (up to $174 \%$ for $100 \mathrm{~g}$ ), and a decrease in the $50 \mathrm{~g}$ variant by $30 \%$ compared to the control.

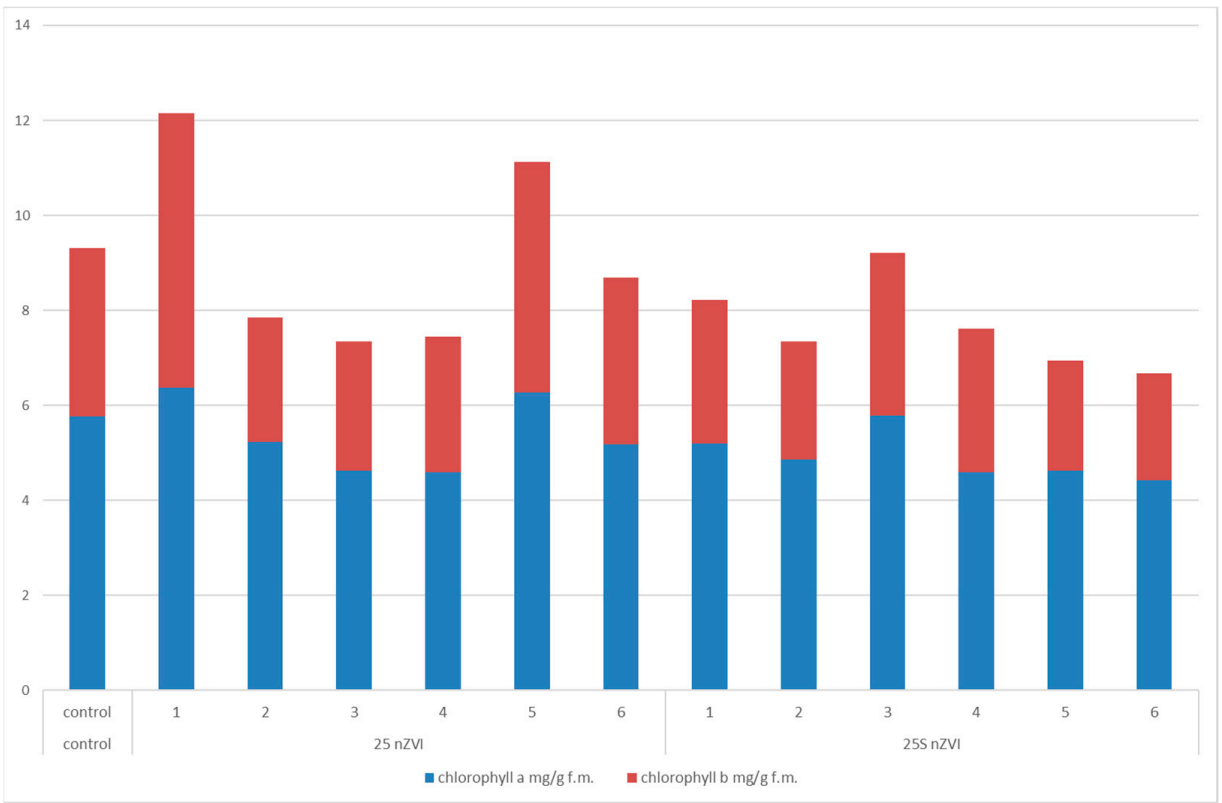

Figure 5. The content of chlorophyll $a$ and chlorophyll $b$ in the shoots of plants grown in soil contaminated with 25 and $25 \mathrm{~S}$ nZVI. The numbers $1-6$ correspond to the following concentrations: $0.5 ; 1 ; 5 ; 10 ; 50$ and $100 \mathrm{~g} \mathrm{nZVI/kg}$ soil. Vertical bars represents the mean values $(n=5) \pm$ standard deviations.

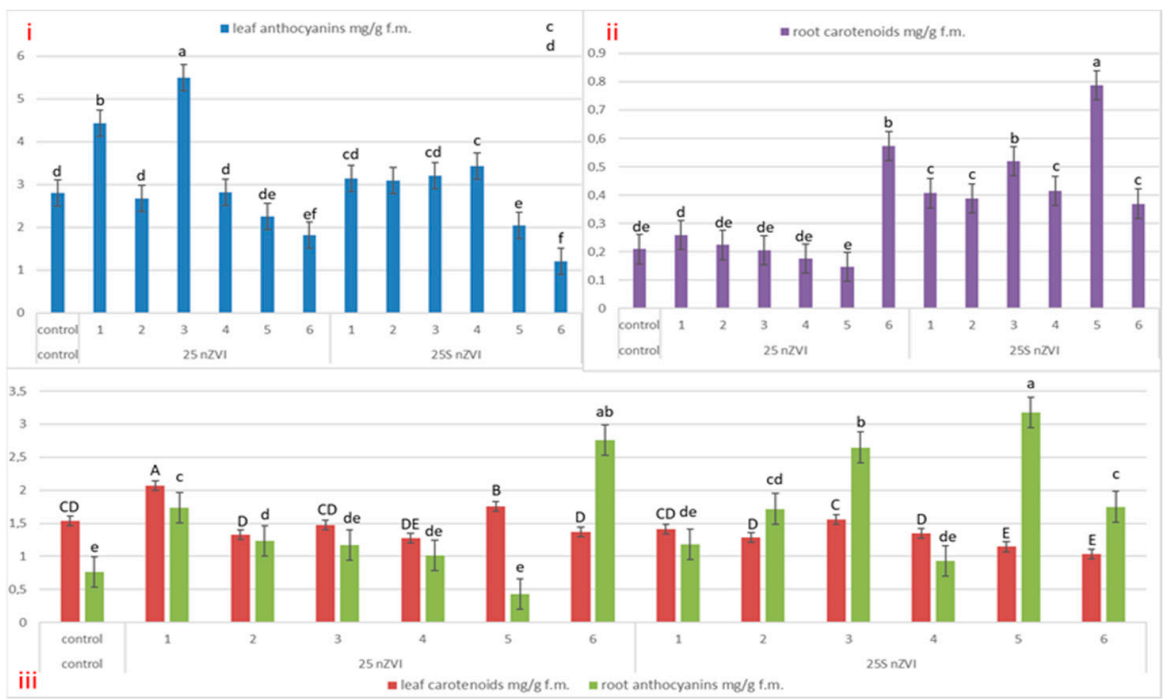

Figure 6. The content of anthocyanins in shoots (i) and roots (iii) and carotenoids in shoots (iii) and roots (ii) of plants grown in soil contaminated with the 25 and $25 S$ nZVI. The numbers $1-6$ correspond to the following concentrations: 0.5 ; 1 ; 5; 10; 50 and $100 \mathrm{~g} \mathrm{nZVI/kg} \mathrm{soil.} \mathrm{Vertical} \mathrm{bars} \mathrm{represents} \mathrm{the} \mathrm{mean} \mathrm{values}(n=5) \pm$ standard deviations. Different letters indicate significant difference at $p<0.05$ by LSD test.

In a study carried out by Wang et al. (2016) a significant decrease in the content of carotenoids was observed; for $1000 \mathrm{mg}$ of $\mathrm{nZVI} / \mathrm{kg}$ soil amendment, concentration was $85.2 \%$. In addition, a significant decrease in the content of photosynthetic pigments was observed, the highest with soil amendment of $1000 \mathrm{mg}$ of nZVI/ $\mathrm{kg}-91.6 \%$ [20]. A similar 
effect was obtained by Martinez-Fernandez and Komarek (2016), who reported a decrease in chlorophyll $a$ and chlorophyll $b$ in the hydroponic cultivation of Solanum lycopersicum L. contaminated with nZVI [23]. Marusenko et al. (2013) observed that the plants treated with No-Fe and NP-Fe had less chlorophyll than the plants treated with EDTA-Fe. At the same time, visual assessment showed yellow leaves in $95 \%$ of plants in No-Fe and NP-Fe treatments, but green leaves in $100 \%$ of plants in EDTA-Fe treatment. The researchers suggest that NP Fe was not used to produce chlorophyll [22].

\subsection{Enzymes Activities-Pyrogallol Peroxidase (POD), Superoxide Dismutase (SOD) and Catalase (CAT)}

The activity of superoxide dismutase in leaves (Figure 7iii) with nZVI increased at a concentration of $10 \%$ and decreased by $13 \%$ for 0.5 and $50 \mathrm{~g}$ (compared to the control). An increase of SOD activity of $21 \%$ was observed for $0.5 \mathrm{~g}$ of nanoFER using $25 \mathrm{~S} \mathrm{nZVI}$, and a $14 \%$ decrease for $10 \mathrm{~g}$ of nanoparticles. The content of catalase activity in the leaves (Figure 8), compared to the control, decreased in all nZVI concentrations used, the least by $32 \%$ at $100 \mathrm{~g}$, the highest by $87 \%$ at $5 \mathrm{~g}$. A similar situation was observed for $25 \mathrm{~S}$ nZVI. These nanoparticles also caused a decrease in CAT activity, the lowest by $32 \%$ for $0.5 \mathrm{~g}$; the highest by $84 \%-1 \mathrm{~g} / \mathrm{kg}$ of dry soil, compared to the control. The strongest effect of iron nanoparticles was observed on pyrogallol peroxidase activity in aboveground parts (Figure 7i). The increase in activity compared to the control was 40-60 fold (less for $25 \mathrm{nZVI}) .25 \mathrm{nZVI}$ and 25S nZVI, in all variants of the experiment, had the same effect on pyrogallol peroxidase activity in the roots (decreased) (Figure 7ii) and superoxide dismutase (increased) (Figure 7iv). A different reaction of the plant to concentrations of soil amendment could be observed by examining the content of catalase in the roots (Figure 8). Almost all concentrations caused a significant increase in enzyme activity compared to the control (even by over $200 \%$ ). The exception was the concentration of $50 \mathrm{~g}$ of $25 \mathrm{nZVI}$ (decrease in activity by $50 \%$ ) and $5 \mathrm{~g}$ of $25 \mathrm{~S}$ nZVI (decrease in activity by $13 \%$ ).

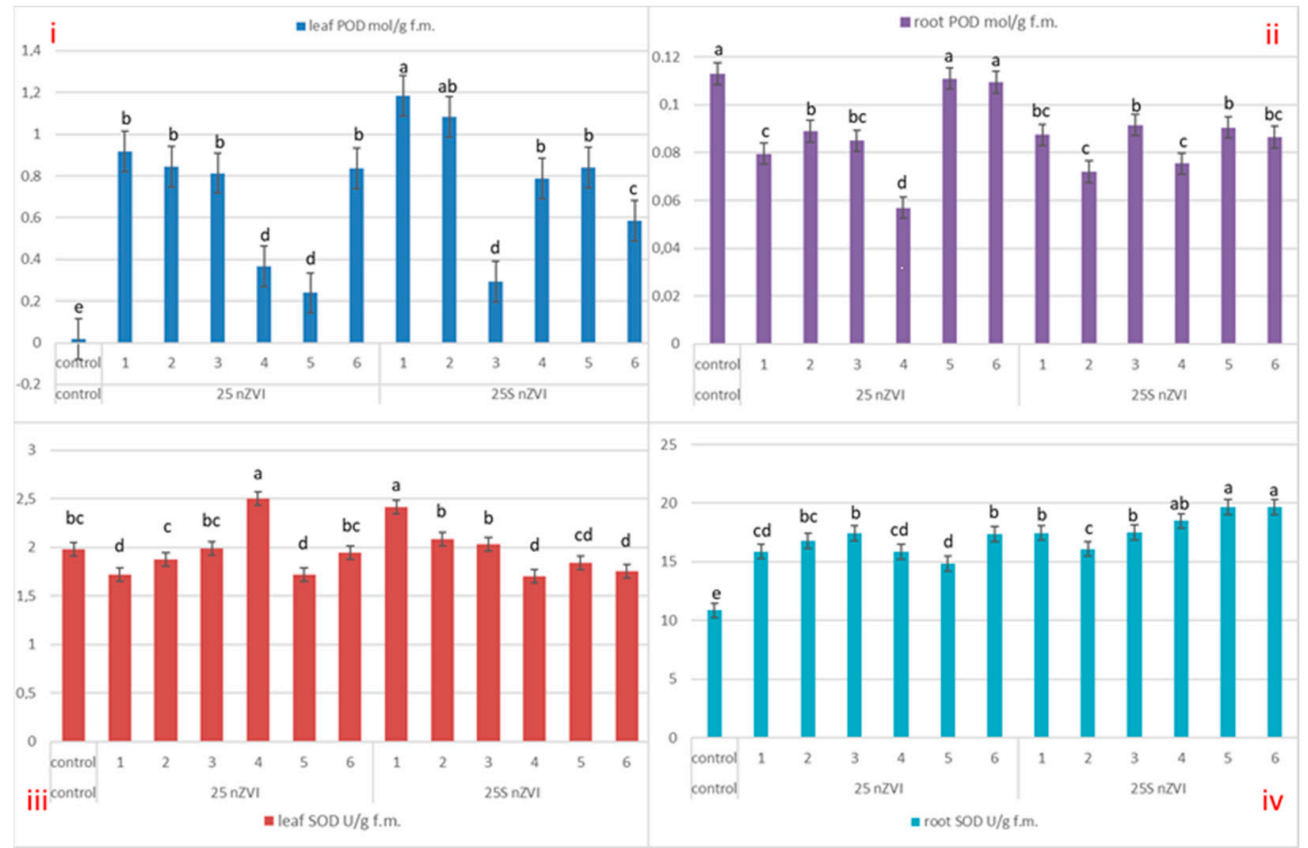

Figure 7. The content of enzymes: Pyrogallol peroxidase (POD) in shoots (i), POD in roots (ii), superoxide dismutase (SOD) in shoots (iii) and SOD in roots (iv) of plants grown in soil contaminated with 25 and 25S nZVI. The numbers 1-6 correspond to the following concentrations: $0.5 ; 1 ; 5 ; 10 ; 50$ and $100 \mathrm{~g} \mathrm{nZVI} / \mathrm{kg}$ soil. Vertical bars represents the mean values $(n=5) \pm$ standard deviations. Different letters indicate significant difference at $p<0.05$ by LSD test. 


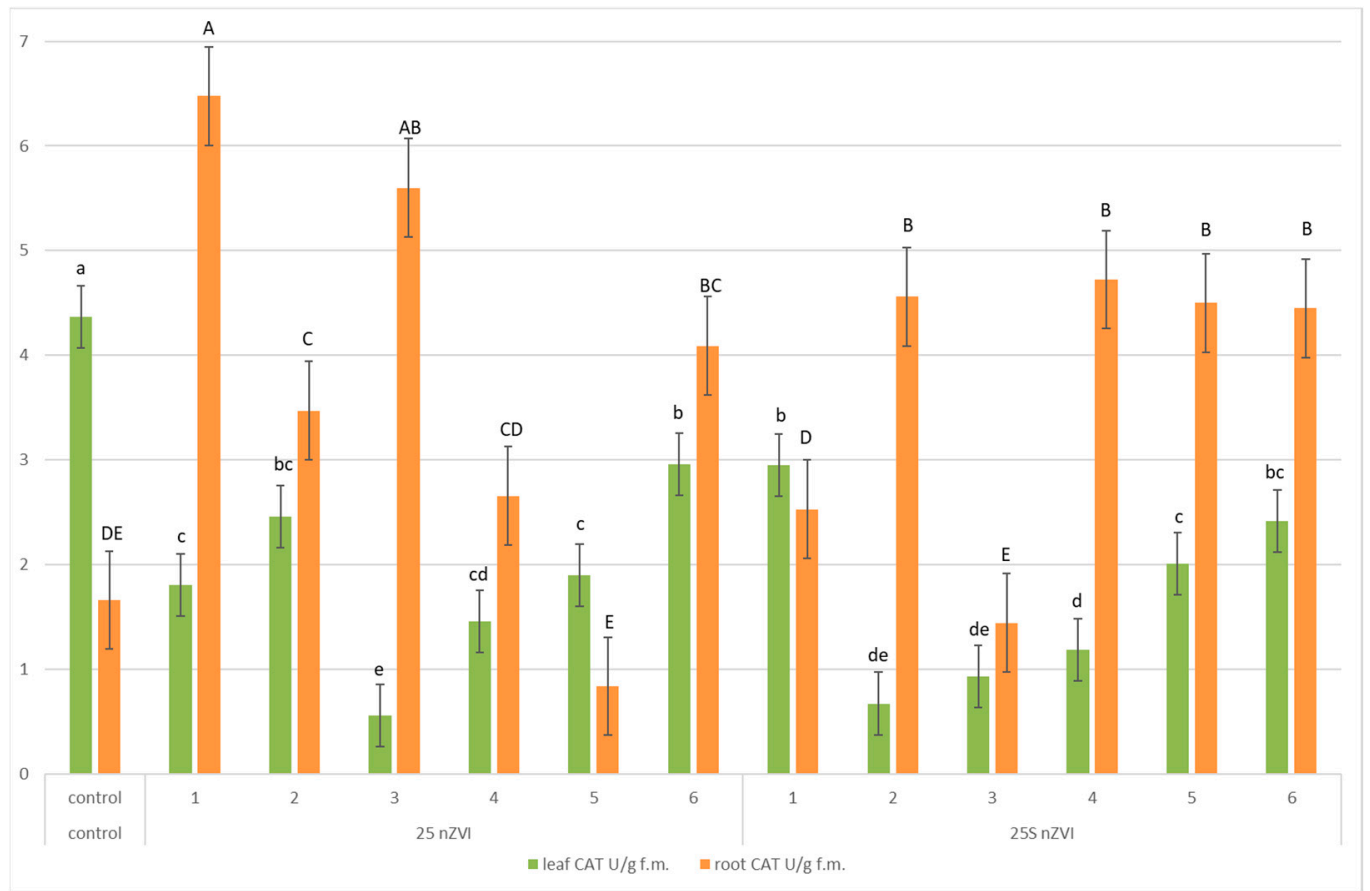

Figure 8. The content of catalase (CAT) in shoots and roots of plants grown in soil contaminated with the 25 and $25 \mathrm{~S}$ nZVI. The numbers $1-6$ correspond to the following concentrations: $0.5 ; 1 ; 5 ; 10 ; 50$ and $100 \mathrm{~g} \mathrm{nZVI} / \mathrm{kg}$ soil. Vertical bars represents the mean values $(n=5) \pm$ standard deviations. Different letters indicate significant difference at $p<0.05$ by LSD test.

According to Wang et al. (2016) pollution at $100 \mathrm{mg} / \mathrm{kg}$ did not affect the enzymes activity of the antioxidant system in the aboveground parts of rice. The concentration of $250 \mathrm{mg}$ of nanoiron $/ \mathrm{kg}$ resulted in inhibition of dismutase by about $20-35 \%$ and increase in peroxidase activity by $36.6 \%$. The activity of catalase was strongly related to the concentration of soil amendment: for $750 \mathrm{mg} / \mathrm{kg}$ it caused a decrease, and $1000 \mathrm{mg} / \mathrm{kg}$ increased activity [20]. Wang et al. (2016) also studied the content of enzymes of the antioxidant system in the roots of plants. They concluded that while POD activity increased with incrementing nZVI concentration, SOD and CAT activity decreased. At a concentration of $100 \mathrm{mg}$ of $\mathrm{nZVI} / \mathrm{kg}$, SOD, POD and CAT activity were not significantly changed compared to the control. Above $250 \mathrm{mg} / \mathrm{kg}$, SOD activity was significantly inhibited (20.4-35.1\%) compared to the control. POD activity was notably promoted $(\sim 36.5 \%)$, compared to the control, when the nZVI concentration was higher than $250 \mathrm{mg} / \mathrm{kg}$. At low concentrations nZVI did not significantly change the activity of CAT compared to the control, while it was inhibited at a dose of $750 \mathrm{mg} / \mathrm{kg}$ and increased for $1000 \mathrm{mg} / \mathrm{kg}$ [20]. Wang et al. (2011) studied the activity of SOD and CAT in shoots and roots of ryegrass (Lolium perenne L.) and pumpkin (Cucurbita mixta) treated with molecular and nanoparticular iron. In the case of ryegrass, the activity of SOD in the roots increased by 166,115 and $110 \%$ at concentrations of 30 and $100 \mathrm{mg}$ of $\mathrm{Fe}_{3} \mathrm{O}_{4} \mathrm{NP} / \mathrm{L}$ and $100 \mathrm{mg}$ of molecular $\mathrm{Fe}_{3} \mathrm{O}_{4} / \mathrm{L}$, compared to the control. The activity of SOD in the ryegrass shoots decreased by $35 \%$ and $46 \%$ when treated with $100 \mathrm{mg}$ of $\mathrm{Fe}_{3} \mathrm{O}_{4} \mathrm{NP} / \mathrm{L}$ and in the molecular form, respectively. On the other hand, the activity of SOD in pumpkin roots increased at a concentration of $30 \mathrm{mg} / \mathrm{L}$ for both forms of $\mathrm{Fe}_{3} \mathrm{O}_{4}$, but decreased when treated with $100 \mathrm{mg} / \mathrm{L}$ for $\mathrm{Fe}_{3} \mathrm{O}_{4} \mathrm{NP}$ and particulate. In pumpkins, SOD activity remained unchanged, regardless the concentrations used. CAT activity in the roots of ryegrass increased by 172,225 and $166 \%$, while it decreased by 40 , 75 and $79 \%$ in the pumpkin roots, after treatment with 30 and $100 \mathrm{mg}$ of $\mathrm{Fe}_{3} \mathrm{O}_{4} \mathrm{NP} / \mathrm{L}$ and $100 \mathrm{mg}$ of $\mathrm{Fe}_{3} \mathrm{O}_{4} \mathrm{BP} / \mathrm{L}$. CAT activity in ryegrass and pumpkin shoots increased significantly after treating NP and $\mathrm{Fe}_{3} \mathrm{O}_{4}$ in an amount of 30 and $100 \mathrm{mg} / \mathrm{L}$ [28]. 


\section{Conclusions}

The conducted experiment showed that nZVI is slightly taken from the soil. The iron passes to the root to a small extent and is not transported further in the plant. In the experiment variant in which $100 \mathrm{~g}$ of $\mathrm{nZVI} / \mathrm{kg}$ was added, only 4 and $5 \mathrm{~g}$ of nZVI (25 and $25 \mathrm{~S}$, respectively) were found in the root. This suggests that iron probably accumulates in the outer layers of the roots or aggregates on their surface and closes further access to the tissues. There is no transport of the nanoFER to the aerial part of the plant or it is negligible. At the same time, it can be observed that nZVI, both in the 25 and $25 \mathrm{~S}$ form, has no toxic effect on plant growth, albeit it reduces the mass of its tissues. The content of polyphenols and flavonoids in aboveground parts of plants decreases with contaminant increase in roots. It is possible that the plant transports these compounds to tissues that have most frequent contact with contaminants. The chlorophyll content in the leaves is strongly related to the concentration of the nZVI; however, no chlorosis was observed in any variant. Similarly, the enzyme activity of the antioxidant system in the whole plant is strongly related to the concentration of the pollutant. The amount of vegetable pigments in the leaves increases for low extents of soil amendment and then decreases at higher levels of contaminants. What was found interesting was that the amount of anthocyanins in the roots using $25 \mathrm{nZVI}$ was varying. The lowest, as well as the highest, concentration of pollutant caused a significant increase in their content. However, for the concentration of $50 \mathrm{~g}$, a decrease in the anthocyanin content was observed. This can be explained by the fact that the Lolium westerwoldicum initially strengthened its antioxidant system to deal with reactive oxygen species, but then lost this ability with high soil amendment.

Comparing the results obtained with the literature it can be concluded that the effect of nZVI on plants depends on the species and the concentrations used, and it cannot be unambiguously determined whether these nanoparticles are toxic.

The results obtained do not give a definite answer whether the use of nZVI is completely safe for ryegrass (Lolium westerwoldicum). Further research is necessary in this direction.

Author Contributions: Conceptualization, B.S. and L.M.-S.; methodology, B.S. and L.M.-S.; SEM analysis, M.S.-J.; formal analysis, L.M.-S.; resources, B.S. and L.M.-S.; data curation, L.M.-S.; writingoriginal draft preparation, L.M.-S. and B.S.; writing-review and editing, B.S.; supervision, B.S. All authors have read and agreed to the published version of the manuscript.

Funding: This research received no external funding.

Institutional Review Board Statement: Not applicable.

Informed Consent Statement: Not applicable.

Data Availability Statement: Data available on request due to limitations related to the intellectual property of the Lodz University of Technology.

Acknowledgments: The authors gratefully acknowledge Surface and Track Analysis Laboratory, Institute of General and Ecological Chemistry, Faculty of Chemistry, Lodz University of Technology, Łódź.

Conflicts of Interest: The authors declare no conflict of interest.

\section{References}

1. Patil, S.S.; Shedbalkar, U.U.; Truskewycz, A.; Chopade, B.A.; Ball, A.S. Nanoparticles for environmental clean-up: A review of potential risks and emerging solutions. Environ. Technol. Innov. 2016, 5, 10-21. [CrossRef]

2. Fajardo, C.; Gil-Díaz, M.; Costa, G.; Alonso, J.; Guerrero, A.; Nande, M.; Lobo, M.; Martín, M. Residual impact of aged nZVI on heavy metal-polluted soils. Sci. Total Environ. 2015, 535, 79-84. [CrossRef] [PubMed]

3. Kim, J.-H.; Lee, Y.; Kim, E.-J.; Gu, S.; Sohn, E.J.; Seo, Y.S.; An, H.J.; Chang, Y.-S. Exposure of Iron Nanoparticles to Arabidopsis thaliana Enhances Root Elongation by Triggering Cell Wall Loosening. Environ. Sci. Technol. 2014, 48, 3477-3485. [CrossRef] [PubMed]

4. El-Temsah, Y.S.; Joner, E.J. Impact of Fe and Ag nanoparticles on seed germination and differences in bioavailability during exposure in aqueous suspension and soil. Environ. Toxicol. 2010, 27, 42-49. [CrossRef] [PubMed] 
5. Lefevre, E.; Bossa, N.; Wiesner, M.R.; Gunsch, C.K. A review of the environmental implications of in situ remediation by nanoscale zero valent iron (nZVI): Behavior, transport and impacts on microbial communities. Sci. Total Environ. 2015, 565, 889-901. [CrossRef]

6. Schmid, D.; Micić, V.; Laumann, S.; Hofmann, T. Measuring the reactivity of commercially available zero-valent iron nanoparticles used for environmental remediation with iopromide. J. Contam. Hydrol. 2015, 181, 36-45. [CrossRef] [PubMed]

7. Grieger, K.D.; Fjordbøge, A.S.; Hartmann, N.I.B.; Eriksson, E.; Bjerg, P.L.; Baun, A. Environmental benefits and risks of zero-valent iron nanoparticles (nZVI) for in situ remediation: Risk mitigation or trade-off? J. Contam. Hydrol. 2010, 118, 165-183. [CrossRef] [PubMed]

8. Rui, M.; Ma, C.; Hao, Y.; Guo, J.; Rui, Y.; Tang, X.; Zhao, Q.; Fan, X.; Zhang, Z.; Hou, T.; et al. Iron Oxide Nanoparticles as a Potential Iron Fertilizer for Peanut (Arachis hypogaea). Front. Plant Sci. 2016, 7, 815. [CrossRef] [PubMed]

9. Nanoiron s.r.o. Nanoiron, Future Technology. 2018. Available online: https://nanoiron.cz/en/news (accessed on 10 November 2020).

10. Wulfsohn, D. Sampling Techniques for Plants and Soil. Landbauforsch. Völk. 2010, 340, 3-30.

11. Hiscox, J.D.; Israelstam, G.F. A method for the extraction of chlorophyll from leaf tissue without maceration. Can. J. Bot. 1979, 57, 1332-1334. [CrossRef]

12. Arnon, D.I. Copper enzymes in isolated chloroplasts. Polyphenoloxidase in Beta Vulgaris. Plant Physiol. 1949, 24, 1-15. [CrossRef] [PubMed]

13. Richardson, A.D.; Duigan, S.P.; Berlyn, G.P. An evaluation of noninvasive methods to estimate foliar chlorophyll content. New Phytol. 2002, 153, 185-194. [CrossRef]

14. Meng, C.C.; Jalil, A.M.M.; Ismail, A. Phenolic and Theobromine Contents of Commercial Dark, Milk and White Chocolates on the Malaysian Market. Molecules 2009, 14, 200-209. [CrossRef]

15. Lamaison, J.L.; Carnat, A. Levels of principal flavonoids in flowers and leaves of Crataegus-Monogyna Jacq and CrataegusLaevigata (Poiret) Dc (Rosaceae). Pharm Acta Helv. 1990, 65, 315-320.

16. Mielcarz-Skalska, L.; Smolińska, B. Response of Lepidium sativum to soil contamination with zinc in molecular and nanoparticle form. World Sci. News. 2018, 114, 55-67.

17. Roth, E.F.; Gilbert, H.S. The pyrogallol assay for superoxide dismutase: Absence of a glutathione artifact. Anal. Biochem. 1984, 137, 50-53. [CrossRef]

18. Chance, B.; Maehly, A. Assay of catalases and peroxidases. Methods Enzymol. 1955, 2, 764-775. [CrossRef]

19. Jiang, M.; Zhang, J. Water stress-induced abscisic acid accumulation triggers the increased generation of reactive oxygen species and up-regulates the activities of antioxidant enzymes in maize leaves. J. Exp. Bot. 2002, 53, 2401-2410. [CrossRef] [PubMed]

20. Wang, J.; Fang, Z.; Cheng, W.; Yan, X.; Tsang, P.E.; Zhao, D. Higher concentrations of nanoscale zero-valent iron (nZVI) in soil induced rice chlorosis due to inhibited active iron transportation. Environ. Pollut. 2016, 210, 338-345. [CrossRef] [PubMed]

21. Ma, X.; Gurung, A.; Deng, Y. Phytotoxicity and uptake of nanoscale zero-valent iron (nZVI) by two plant species. Sci. Total Environ. 2013, 443, 844-849. [CrossRef] [PubMed]

22. Marusenko, Y.; Shipp, J.; Hamilton, G.A.; Morgan, J.L.; Keebaugh, M.; Hill, H.; Dutta, A.; Zhuo, X.; Upadhyay, N.; Hutchings, J.; et al. Bioavailability of nanoparticulate hematite to Arabidopsis thaliana. Environ. Pollut. 2013, 174, 150-156. [CrossRef] [PubMed]

23. Martínez-Fernández, D.; Komárek, M. Comparative effects of nanoscale zero-valent iron (nZVI) and $\mathrm{Fe}_{2} \mathrm{O}_{3}$ nanoparticles on root hydraulic conductivity of Solanum lycopersicum L. Environ. Exp. Bot. 2016, 131, 128-136. [CrossRef]

24. Gil-Díaz, M.; González, A.; Alonso, J.; Lobo, M. Evaluation of the stability of a nanoremediation strategy using barley plants. J. Environ. Manag. 2016, 165, 150-158. [CrossRef] [PubMed]

25. Yirsaw, B.D.; Megharaj, M.; Chen, Z.; Naidu, R. Environmental application and ecological significance of nano-zero valent iron. J. Environ. Sci. 2016, 44, 88-98. [CrossRef] [PubMed]

26. Fazlzadeh, M.; Rahmani, K.; Zarei, A.; Abdoallahzadeh, H.; Nasiri, F.; Khosravi, R. A novel green synthesis of zero valent iron nanoparticles (NZVI) using three plant extracts and their efficient application for removal of $\mathrm{Cr}(\mathrm{VI})$ from aqueous solutions. Adv. Powder Technol. 2017, 28, 122-130. [CrossRef]

27. Wang, Z.; Fang, C.; Megharaj, M. Characterization of Iron-Polyphenol Nanoparticles Synthesized by Three Plant Extracts and Their Fenton Oxidation of Azo Dye. ACS Sustain. Chem. Eng. 2014, 2, 1022-1025. [CrossRef]

28. Wang, H.; Kou, X.; Pei, Z.; Xiao, J.Q.; Shan, X.; Xing, B. Physiological effects of magnetite $\left(\mathrm{Fe}_{3} \mathrm{O}_{4}\right)$ nanoparticles on perennial ryegrass (Lolium perenne L.) and pumpkin (Cucurbita mixta) plants. Nanotoxicology 2011, 5, 30-42. [CrossRef] [PubMed] 